\title{
Turizm gelirleri ve dış borçlanma arasındaki ilişki: Türkiye üzerine ampirik bir inceleme
}

\author{
The relationship between tourism revenues and external borrowing: an empirical analysis on \\ Turkey
}

Emre Demir ${ }^{1}$ ve Ozan Bahar ${ }^{2}$

${ }^{1}$ Doktora Öğrencisi, Muğla Sıtkı Koçman Üniversitesi, Muğla/Türkiye, e-mail: emredemir3407@gmail.com ORCID: https://orcid.org/00000001-7881-9575

${ }^{2}$ Prof. Dr., Muğla Sitkı Koçman Üniversitesi, Muğla/Türkiye, e-mail: obahar@mu.edu.tr ORCID: https://orcid.org/0000-0003-3349-5479

\begin{tabular}{|c|c|}
\hline Makale Bilgisi & $\ddot{O} z$ \\
\hline Araştırma Makalesi & $\begin{array}{l}\text { Turizm gelirleri ve dış borçlar, ülke ekonomilerine döviz cinsinden fon kaynağl sağlayan } \\
\text { önemli değiskenler arasında yer almaktadır. Bu hususta çalısmanın amacl, Türkiye ekono- }\end{array}$ \\
\hline Gönderilme:16 Aralık 2021 & misi için turizm gelirleri ile dış borçlanma arasındaki ilişkiyi ortaya koymaktır. Bu amaçla \\
\hline Düzeltme: 25 Ocak 2022 & Türkiye'de turizm gelirleri ile dış borçlanmalar arasındaki ilişki Johansen-Juselius (1990) \\
\hline Kabul: 29 Ocak 2022 & $\begin{array}{l}\text { Eşbütünleşme yöntemi ve Granger Nedensellik analizi yardımiyla } 2003 \text { Q1 ve } 2021 \text { Q1 dö- } \\
\text { nemi arasında cevreklik veriler kullanılarak test edilmistir. Elde edilen bulgulara göre ilgili }\end{array}$ \\
\hline Anahtar kelimeler: & seriler arasında bir tane eşbütünleşme ilişkisi bulunmuş ve bu bağlamda hata düzeltme me- \\
\hline Turizm gelirleri, & kanizmasının çalıştığı görülmüşsür. Analizde ilişkinin yönünün turizm gelirlerinden, dış \\
\hline Dış borçlanmalar, & borçlanmaya doğru olduğu ve uzun dönemde turizm gelirlerinde meydana gelen \%1'lik ar- \\
\hline Türkiye ekonomisi, & tışın, ilgili dönemde dış borçlarda \%0.262 oranında bir azalmaya sebep olduğu tespit edil- \\
\hline $\begin{array}{l}\text { Johansen eşbütünleşme, } \\
\text { Hata düzeltme modeli. }\end{array}$ & $\begin{array}{l}\text { miştir. Yapılan araştırma, Türkiye ekonomisi için literatüre kazanımı açısından ele alınan } \\
\text { konu cercevesinde oldukca önem arz etmektedir. }\end{array}$ \\
\hline Nedensellik analizi & \\
\hline
\end{tabular}

Nedensellik analizi

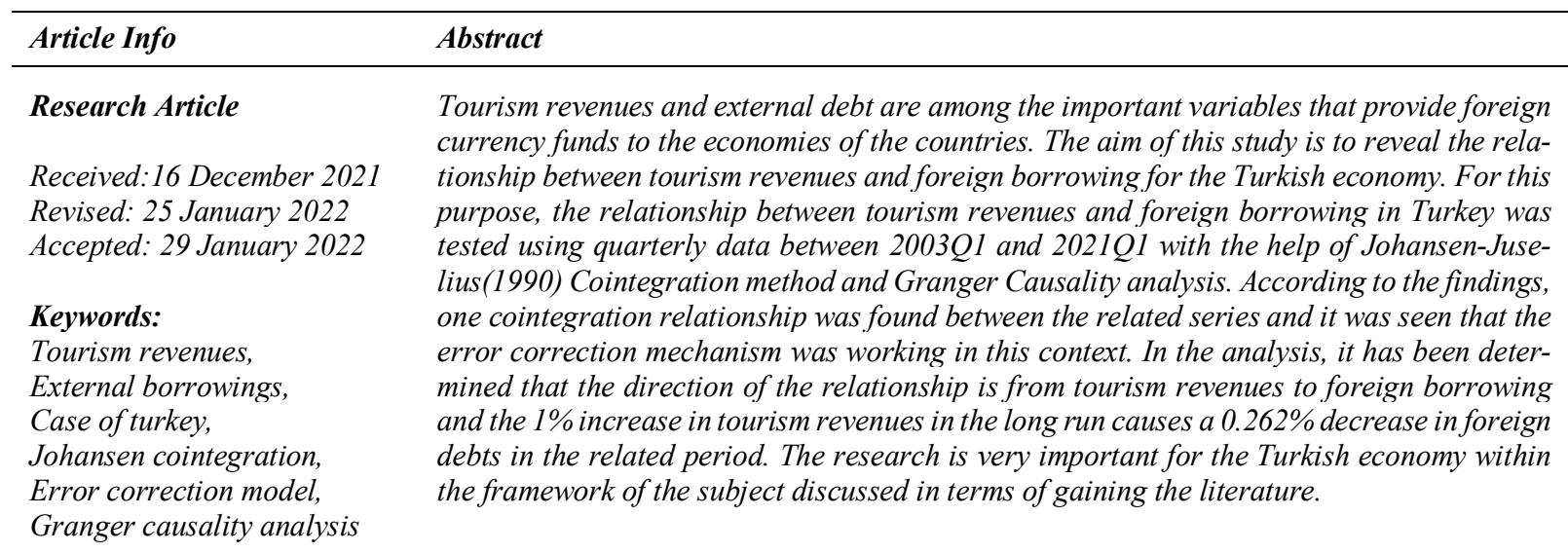

\section{Giriş}

Ülke ekonomilerinde yaşanan tasarruf yetersizliği ve likidite sıkışıklığı, kalkınmanın ve gelişmenin önündeki en büyük engel konumundadır. Dolayısıyla iktisadi gelişmenin sağlanması için gerekli kaynakların temini ya da elde edilmesi elzem niteliktedir. Bu bağlamda ülke ekonomileri için döviz cinsinden fon sağlayan turizm gelirleri ve dış borçlanmalar oldukça önemli iki değişken olarak karşımıza çıkmaktadır.

\footnotetext{
*Bu çalışma ekonomi alanında olup 2003Q1 ve 2021Q1 dönemi arasında çeyreklik verileri kullanmıştır. İnsan üzerine veri, toplama, analizi ya da sonuçları ile ilgili olmadığı için Etik Kurul Onayı gerekmemektedir. Tüm sorumluluk yazara aittir.

Kaynak göster: Demir, E. \& Bahar, O. (2022). Turizm gelirleri ve dış borçlanma arasındaki ilişki: Türkiye üzerine ampirik bir inceleme. International Journal of Social Sciences and Education Research, 8 (1), 99-110. DOI: https://doi.org/10.24289/ijsser.1037293
} 
II. Dünya Savaşı sonrasında dünya ekonomilerince takip edilen Keynesyen politikalar çerçevesinde, iktisadi gelişmenin sağlanması için gerekli fon ihtiyacının karşılanması amacıyla ekonomiler sürekli olarak dış kaynaklara başvurmuştur. Döviz cinsinden fon açığının giderilmesi için başvurulan bu dış borçlanmaların yanında turizm gelirleri, dönemsel perspektifte, oldukça önemli bir döviz kaynağı niteliği haline gelmiştir. Çünkü yaşanan küresel dönüşümler içerisinde turizm, teknolojinin ve refahında etkisiyle oldukça popüler hale gelmiş, birçok açıdan çeşitlilik kazanmış ve ülke ekonomilerinin ihtiyaç duyduğu yabancı para cinsinden fon açığının giderilmesinde önemli bir sektör niteliği kazanmıştır. Öyle ki yaşanan bu ekonomik ve sosyal gelişmeler kapsamı altında, Birleşmiş Milletler (UN) bünyesinde yer alan Dünya Turizm Örgütü’ne (WTO) göre turizm, dünyanın en büyük ve en geniş kapsamlı bir ekonomik faaliyet alanı olarak betimlenmiştir (Cho, 2003). Böylece dış borçlanmaların yanında turizm, elde edilen döviz gelirleri ile ülkelerin iktisadi gelişmesinde önemli bir kaynak haline gelmiş ve ülkeler bu kaynaktan daha fazla pay alabilmek adına büyük yatırımlara girişmişlerdir (Gökovalı ve Bahar, 2006). Dolayısıyla turizm, kazanımları sebebiyle hem gelişmiş hem de gelişmekte olan ülkelerde büyük ilgi görmüştür (Jayawardena ve Ramajeesing, 2003: 176). Turizm sektörüne olan bu ilgi, özellikle dış borç miktarının yüksek olduğu ve yabancı para cinsinden fon açığı bulunan ülke ekonomilerinde daha çok ön plana çıkmıştır.

Gelişmekte olan Türkiye ekonomisi için döviz girdisi sağlayan çeşitli makroekonomik değişkenler bulunmaktadır. Ancak bunların içerisinde turizm gelirleri ve dış borçlanmalar oldukça önemli iki değişken arasında yer almaktadır. Çünkü uluslararası turizm sektörü söz konusu olduğunda Türkiye'nin sahip olduğu potansiyel, bu gelirlerin elde edilebilmesi için oldukça büyük avantajlar sağlamaktadır. Türkiye, bu avantajlardan yararlanabilmek için, özellikle 1980 sonrasında, önemli yatarımlar gerçekleştirmiş ve uluslararası turizm gelirlerinden aldığı payı yükseltmeye çalışmıştır. Ancak Türkiye'de artan yatırımlar için gerekli fon ihtiyacının karşılanabilmesi amacıyla dış borçlanmalara başvurulmuş ve bu sebeple, 1980 sonrasında dış borçlanmalardaki artışın hızla yükseldiği görülmüştür.

Bu araştırmanın amacı, Türkiye'de turizm gelirleri ile dış borçlanmalar arasındaki ilişkiyi ortaya koymaktır. Bu bağlamda 2003Q1 ve 2021Q1 yılları arasında çeyreklik veriler ile bu ilişki, Johansen Eşbütünleşme ve Granger Nedensellik yöntemi yardımıyla analiz edilmiştir. Çalışma, literatüre kazanımı açısından oldukça önemlidir. Çünkü spesifik olarak Türkiye'de turizm gelirleri ve dış borçlanma arasındaki ilişkiye dair daha önceden yapılan bir çalışmaya rastlanmamaktadır. Dolayısıyla bu iki değişken arasındaki ilişkinin ortaya konulması, yeni bir yorumun ortaya çıkmasını da sağlamaktadır. Çalışmanın geri kalanı şu şekilde devam etmektedir: Turizm gelirleri ve dış borçlanma arasındaki ilişkiye dair gerekli çerçevenin ele alınması; Türkiye'de turizm gelirleri ve dış borçlanmaya ilişkin verilerin açıklanması; analiz ve bulgulara yer verilmesi ve son olarak sonuç ve tartışmanın sunulmasidir.

\section{Turizm gelirleri ve dış borçlanma ilişkisi}

II. Dünya Savaşı sonrasında dünyada var olan küreselleşmenin hızla artması ve yeni bir dönüşüm içerisine girilmesinden sonra ülke ekonomilerinin birbirine entegre olacak şekilde uyguladığı politikalar neticesinde turizm, hızlı bir gelişme göstermiştir (Demir ve Bahar, 2021: 162). Dış borçlanmaların ise bu gelişmenin hız kazanmasında büyük rol oynadığını söylemek mümkündür. Çünkü ülkeler, yatırımlar için gerekli fon ihtiyacını karşılamak amacıyla bu borçlanma yoluna gitmek durumunda kalmış, bu sebeple dünya ekonomilerinin sahip olduğu dış borç yükü hızla artmıştır.

Dış borçlanmalarda yaşanan gelişmeler şüphesiz ki 1929 Büyük Buhran'a dayanmaktadır. Kriz döneminde yaşanan ekonomik bunalımın önüne geçmek amacıyla uygulamaya konulan Keynesyen politikalar çerçevesinde bütçe dengesi, önceki iktisadi anlayışa nazaran önemsenmemiş ve borçlanma, basit bir finansman aracına dönüşmüştür. Çünkü Keynesyen politikalar çerçevesinde durgunluk döneminde bütçeyi dengelemeye gerek olmadığını görüşü hakimdir (Yılmaz, 2010: 13). Bu bağlamda genişletici maliye politikalarının uygulanması amacıyla ülke ekonomilerinin ihtiyaç duyulan fonlar, dış kaynaklardan temin edilmeye başlanmış ve bu araç, önemli bir maliye politikası aracı olarak görülmüştür. Böylece yatırımların dış borçlanma yoluyla finanse edilmesi, iç kaynaklarla yapılamayacak kadar büyük yatırımların yapılmasına imkân vermiştir (Tuna, 2019: 12). Bu görüş ve politika çerçevesinde dışarıdan sağlanan mali kaynakların yurtiçi kaynak arzındaki açığı azaltarak/gidererek iktisadi gelişmeyi olumlu etkilemiştir (Seyidoğlu, 2003: 756).

Diş borçlanma, daha çok gelişmekte olan ülkelerin (GOÜ) başvurduğu bir ekonomi kalemi olmakla beraber, gelişmiş ülkelerinde başvurmakta olduğu önemli fon kaynağı olma niteliği taşımaktadır. Gelişmiş ülkelerin kalkınma süreçleri incelendiğinde, bu ülkelerin gerekli fon eksikliklerini gidermek adına dış borca başvurmuş oldukları görülmektedir. Gelişmiş ülkelerinden olan İngiltere, İsveç, Amerika Birleşik Devletleri (ABD), Japonya gibi ülkeler bu kıssasın örneklerini teşkil etmektedir (Türk, 2003: 278). Dış borçlanmalar, ekonomilerde hem iç tasarruf Copyright (C) 2022 by IJSSER 
yetersizliğini gidermekte hem de yabancı para cinsinden ödeme gücü sağlamaktadır. Dış borçlanma yapıldığında iç kaynaklarda artış görülmekle beraber, geri ödendiğinde de azalışlar meydana gelebilmektedir. Bu sebeple dış borç kalemine başvuran ekonomilerin aldıkları borcu verimli alanlarda kullanması açısından gereklilik, dış borcun geri ödenmesi sırasında ekonomi dinamiklerinde zorluk yaşanmaması bakımından önemli bir unsurdur (Demir, 2018: 2). Bu hususta turizm sektörü, elde edilen turizm gelirlerinin dış borçlanmalar gibi döviz cinsinden olması sebebiyle, ülkeler için temin edilen dış fonlar çerçevesinde verimli bir yatırım pozisyonu olarak görülmesi olağandir.

Turizm gelirlerini arttırmak için ülkelerin yapmış olduğu yatırımların büyüklüğü, bu ülkelerinde harcamalarını artırmakta ve yeni fon arayışına itmektedir. Bu fon ihtiyacının iç kaynaklardan temin edilememesi, ülkeleri dış kaynaklara yöneltmesi olağandır. Bu yönelimin oluşturduğu maliyetlerin temini, aslen yatırım yapılan turizm sektöründen beklenebilir. Dolayısıyla bu bağlamda yatırıma bağlanan fon miktarı ne kadar büyük olursa, beklenen gelirde o denli büyük olabilir. Bu hususta ülke ekonomileri için turizm gelirleri ve dış borçlanmaların niteliğinin benzerlik taşıdığını söylemek mümkündür. Bu benzerlik içerisinde bu iki değişkenin de yabancı para cinsinden olması önce gelmektedir.

Ülke ekonomileri açısından döviz cinsinden elde edilecek olan gelirler oldukça önemlidir. Çünkü bu gelirler; ülkeler için uluslararası bir ödeme gücü yaratmakta, yeni yatırımlara olanak tanımakta, dış ticaretin büyümesini sağlamaktadır. Bu gibi faktörler, kümülatif olarak ülkelerin iktisadi gelişimini desteklemektedir (Pearce, 1991; Sharpley, 2002). Bu hususta turizm sektörünün gelişmesi, bu sektörden alınacak olan uluslararası gelir payının yükselmesini sağlarken, bu gelirler ülke ekonomisi için aynı zamanda yabancı para cinsinden bir likitide olanağı yaratmaktadır. Elde edilen bu gelirler, bu sektör için kullanılan dış kaynaklar içinde bir ödeme kaynağı teşkil edebilir. Bu suretle, söz konusu iki değişken arasındaki ilişkinin varlığı, ülke ekonomilerinin uyguladığı veya takip ettiği politikalar çerçevesinde ortaya konulabilir. Bahsedilen bu politikalar, dünyada ülke ekonomilerinin ortak hedefi olan istikrarlı bir ekonomik büyüme ve kalkınma ile ilişkilidir. Bu çıkarımlar altında, turizm gelirleri ve dış borçlanma arasında bir "tamamlayıcılık" ilişkisinin varlığından söz edilebilir.

Teorik açıdan bu iki değişken ülke ekonomileri için bir "çarpan mekanizması" görevi görmektedir. Bu bağlamda ülke ekonomileri için turizm, toplam talebin dışsal bir bileşeni olarak kabul edilebilmektedir. Bu durum, aynı şekilde dış borçlar içinde geçerlidir (Ay, 2013: 219). Ülkeler için gerek turizm gelirleri gerekse dış borçlanmalar, toplam talepte bir artışa sebep olabilmekte ya da tam aksine toplam talepte bir azalışa neden olabilmektedir. Ancak belirtilmesi gereken, spesifik olarak bu iki değişken arasındaki ilişki üzerinde herhangi bir teorik inceleme ve görüş literatürde yer almamaktadır.

Sektörel açıdan turizmin büyüme ve gelişme yılları tesadüfi değildir. II. Dünya Savaşı sonrasında yaşanan ekonomik gelişmeler, sektörün büyümesini sağlamış ve ülkelerce önemli bir konumda yer almayı başarmıştır. Bu temel başarılar altında dünya ekonomilerinin artan refahı yer alsa da refahı artmamış ya da geri kalmış ülkelerde bu durum farkll1ık gösterebilir. Gelişmekte olan ya da gelişmemiş ülkelerin sahip olduğu kaynak yetersizliği sebebiyle bu sektöre daha fazla önem vermesi olağan olmakla birlikte, yine ülke ekonomilerinin sahip olduğu dış borç yükü de turizm sektörüne verilen önemi arttırmaktadır. Diğer bir ifadeyle gelişmiş ülkeler gibi katma değeri yüksek mallar üretemeyen ülkeler, döviz geliri elde etmek için turizm sektörünü önemli bir araç olarak görmektedirler. Bu gelişmeler altında turizm sektörü hızla gelişerek, dünyada en önemli sektörlerden biri olmaya başarmıştır. Lakin bu konjonktürdeki asıl vurgu, dönemsel çerçevede ülkelerin dış borç artışları ile turizm gelirleri artışının paralel bir yapıya sahip olmasıdır.

Özetle, bu iki değişken arasındaki ilişki tamamlayıcı etkenlere dayanabilir. Turizm sektörünün gelişmesi ve büyümesi amacıyla belirlenen hedeflerin gerçekleştirilebilmesi için dış borçlanmalara başvurulabilir ya da kullanılan dış borçlanmaların tediyesinde ülkeler turizm gelirlerinden faydalanabilir. Ayrıca turizm gelirlerindeki artışa hitaben elde edilen döviz girdisinin büyüklüğü sebebiyle ülkeler borç temininde daha fazla kaynağa ulaşabilir ya da elde edilen dış borçlanmaların kullanım alanlarına göre daha fazla turizm geliri elde edilebilir. Buradaki ilişkinin yönü ve belirleyicileri, ülke ekonomilerinin gelişmişlikleri ve araştırılan dönemlerde uygulanan politikalar ile değişiklikler gösterebilir.

\section{Türkiye'de turizm gelirleri ve dış borçlanmalar}

Türkiye ekonomisinde, diğer gelişmekte olan ülkelerde olduğu gibi, döviz girdisi sağlayan faktörler ekonomi için oldukça önemli bir yer tutmaktadır. Çünkü Cumhuriyet'in ilk yıllarından itibaren Osmanlı'dan kalan borçları devralan Türkiye Cumhuriyeti (Karluk, 2007: 164) hem bu borçları ödemek hem de tasarruf açıı̆ını kapatmak üzere başvurduğu dış borçların tediyesi için döviz cinsinden likitide ihtiyacı içinde olmuştur. İhtiyaç duyulan bu 
fon miktarı, aynı zamanda döviz geliri sağlayan sektörler için de bir baskı oluşturmuş ve bu baskı, neticesinde döviz girdisi elde edilen sektörlerin de gelişmesine katkı sağlamıştır.

Türkiye'de turizm sektörü incelendiğinde; bu sektöre ilişkin nihai adımların 1980’li yıllarda atıldığını ve bu tarihten itibaren sektörün önemli bir gelişme kaydettiğini söylemek mümkündür. Bu bağlamda 1980’li yıllardan itibaren önemli gelişmeler kaydeden turizm sektörü, özellikle 2000'li yıllardan sonra hem Türkiye'de hem dünyada yaşanan gerek ekonomik gerek sosyal ve kültürel gelişmelere paralel çerçevede hızlı artışlar göstermiştir (Yavuz, 2006: 162). Ancak turizmde yaşanan bu gelişmelerin takibinde Türkiye'nin dış borç miktarlarında da artışlar yaşanmıştır. Özellikle son 20 yılda, özel sektör borçlarında meydana gelen artışların, turizm sektörüne yapılan özel sektör yatırımları ile de ilişkilendirmek mümkündür. Çünkü turizm yatırım ve işletmeciliğinde özel sektör esastır. Yani devlet öncülüğünde başlayan turizm için alt yapı yatırımları, akabinde özel sektör ile yerini üst yapıya devretmekte ve bu doğrultuda ancak devlet teşvikleri yer almaktadır. Bu bağlamda Türkiye'de, ülke menfaatleri doğrultusunda 12 Mart 1982'de çıkarılan “Turizmi Teşvik Kanunu” önemli bir örnek niteliği taşımaktadir.

Grafik 1. Türkiye'de turizm gelirleri ve dış borç stoku

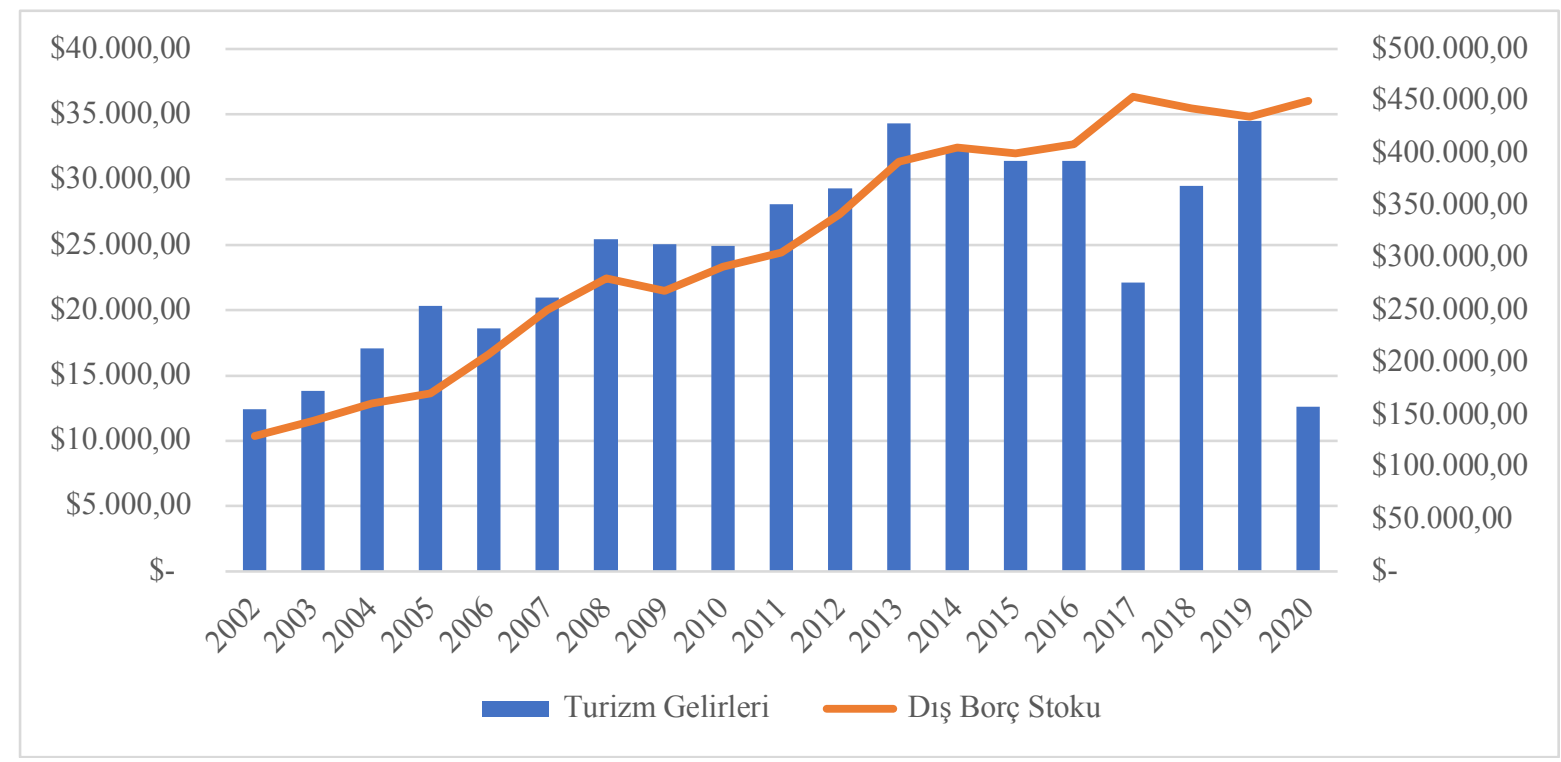

Kaynak: Dünya Bankası

Türkiye'de araştırmaya dahil edilen yıllarda turizm gelirleri ve dış borç stoku Grafik 1.'de gösterilmektedir. Grafikte de görüldüğü üzere, ele alınan yıllarda Türkiye'nin turizm gelirleri ve dış borç stokunda önemli derecede artışlar meydana gelmiştir. Bu sonuç, uluslararası eğilime de bağlı olarak gerçekleşmiştir. Ancak 2009, 2017 ve 2020 yıllarında turizm gelirlerinin oldukça düştüğü ve bu yıllarda dış borçlarda yüksek artışlar meydana geldiği görülmektedir. Söz konusu içerisinde 2017 yılı için ulusal çapta yaşanan olumsuz bir gelişmeden kaynaklı olarak turizm gelirlerinde bir azalmanın meydana geldiğini; 2009 ve 2020 yılları için ise uluslararası çapta yaşanan Küresel Ekonomik Kriz ve COVID-19 krizinin etkileri sebebiyle turizm gelirlerinde bir azalma meydana geldiğini ifade etmek mümkündür.

Türkiye ekonomisi için araştırmaya dahil edilen yıllar içerisinde Türkiye ekonomisinin sahip olduğu diş borç yükü sebebiyle turizmden elde edilen döviz girdileri önemlidir. Çünkü Türkiye, diğer gelişmekte olan ülkelerde olduğu gibi, diğer makroekonomik faktörlerden yeterince elde edemediği döviz girdilerini turizm gelirleri ile desteklemektedir. Dolayısıyla turizmden elde edilecek gelirler, Türkiye'nin dış borç tediyesi sırasında yaşanan döviz açı̆̆ının giderilmesinde önemli bir destek sağlamaktadır.

\section{Veri seti ve yöntem}

Türkiye'de turizm gelirleri ile dış borçlanmalar arasındaki ilişkinin araştırılabilmesi için Johansen -Juselius Eşbütünleşme yöntemi kullanılmış olup, analize 2003Q1 ila 2021Q1 yılları arasındaki çeyreklik veriler dahil edilmiştir. Araştırmaya ilişkin veriler Türkiye Cumhuriyeti Merkez Bankası Elektronik Veri Dağıtım Sisteminden (TCMB EVDS) temin edilmiştir (2021). İlgili veriler ve bu verilere ilişkin kullanılan semboller Tablo 1.'de yer almaktadir. 
Tablo 1. Araştırmada kullanılan değişkenler

\begin{tabular}{|l|l|}
\hline TN & Turizm gelirleri (tourism income) (ABD Doları) \\
\hline EX & Brüt diş borç stoku (external debt) (ABD Doları) \\
\hline
\end{tabular}

Tablo 1.'de görüldüğü üzere çalışmada iki adet değisşken kullanılmış olup, bu değişkenler dolar cinsinden temin edilmiştir. Akabinde her iki değişkende logaritmik formda kullanılmıştır. Eşbütünleşme analizi, seriler arasında uzun dönemli bir denge ilişkisinin olup olmadığını inceleyen bir süreçtir. Seriler eşbütünleşik ise kısa ve uzun vadeli veriler için genelleştirilmiş Granger nedensellik aranmalıdır. Hata düzeltme modelinde hata düzeltme mekanizması kullanılarak seriler arasındaki kısa ve uzun vadeli ilişkilerde ortaya çıkan dengesizlik ile eşbütünleşme bağımlılı̆̆ı olan değişkenler arasındaki kısa ve uzun vadeli dengedeki sapmalar düzeltilebilir. Hata terimlerinin düzey değerlerinin durağan olması halinde seriler arasında eş-bütünleşme ilişkisinin olduğu hipotezi kabul edilir. Eş-bütünleşme analizlerinde yaygın olarak kullanılan bir başka teknik ise Johansen -Juselius (1990) tarafindan ileri sürülmüştür. Burada karakteristik köklerin sıfira eşit olup olmadığı test edilmektedir. Eş-bütünleşme ilişkisinin varlığının irdelenmesi için iki test öne sürülmüştür. Bunlar aşă̆ıdaki gibidir (Ceylan ve Başer, 2014: 54):

$$
\begin{aligned}
& \lambda_{\text {trace }}(r)=-T \sum_{i=r+1}^{n} .\left[\ln \left(1-\lambda_{i}\right)\right] \\
& \lambda_{\text {trace }}(r, r+1)=-T \ln \left(1-\lambda_{i+1}\right)
\end{aligned}
$$

Yukarıda ifade edilen (1) no'lu denklemde yer alan $\lambda \mathrm{i}$, matrislerden elde edilen karakteristik kökler ve $\mathrm{T}$ gözlem sayısını ifade etmektedir. Genel bir alternatife karşı r'ye eşit veya daha az sayıda eş-bütünleşme vektörü olduğunu ileri süren temel hipotez değerlendirilir. Tüm karakteristik köklerin değeri istatistiksel olarak sıfir olduğunda testin değeri de sıfır olmaktadır. (2) no'lu denklem ise, temel hipotezde $r$ kadar eş-bütünleşme vektörü olduğu hipotezi, r+1 eş-bütünleşme vektörü olduğunu ileri süren alternatif hipoteze karşı test edilmektedir.

Eş-bütünleşme ve hata düzeltme modelleriyle yapılacak olan analiz temel olarak beş aşamalı sürece tabidir. $\mathrm{Bu}$ aşamalar aşağıda sıralanmaktadır (Demir ve Bahar, 2021: 169):

- Modelde yer alan değişkenlerin bütünleşme önceliği belirlenir.

- $\quad$ Augmented Dickey Fuller (ADF) testleriyle seriler durağan hale getirilir.

- Uygun gecikme uzunluğu Vector Otoregresyon ile test edilir.

- Eşbütünleşme yöntemi uygulanarak değişkenler arasında eş-bütünleşme ilişkisi incelenir.

- Eşbütünleşik olan serileri nedensellik analizine tabii tutulur.

Değişkenlerin eşbütünleşme ilişkisi içinde olup olmadıklarına karar verebilmek için hata terimleri serisine ADF testi uygulanır. Aksi halde eşbütünleşme ilişkilerinin varlığından söz edilemez. Uygulanan bu test sonucunda hata terimleri serisinin durağan çıkması halinde söz konusu değişkenlerin eş-bütünleşme ilişkisi içerisinde olduğuna karar verilir. Tersi durumda ise eş-bütünleşme ilişkinsin varlığından söz edilemez. Hata terimleri sersinin denklemi aşağıdaki denklem şeklinde tanımlamak mümkündür.

$$
\Delta_{e}=h_{1} * e_{t-1+\varepsilon_{t}}
$$

Yukarıdaki (3) no'lu denklemde yer alan $h_{1}$ modelin temel hipotezini ifade ettiği için burada kurulan temel hipotez şu şekildedir;

$H_{0}$ : Birim kök vardır seri durağan değildir

$H_{1}$ : Birim kök yoktur seri durağandır

Dolayısıyla bu temel hipotezlerden $H_{0}$ hipotezi reddediliyorsa et sersinin durağan olduğu ve modelde kullanılan değişkenlerin eş-bütünleşik ilişki içerisinde olduklarına karar verilir.

Araştırmada kullanılan değişkenlerin durağanlığı analizlerde yaygın olarak kullanılan birim kök testlerinden biri Dickey-Fuller (1982) tarafindan geliştirilen Augmented Dickey-Fuller (ADF) testi ile analiz edilmiş̧ir. Dolayısıyla durağan olmayan veri setleri ile yapılan analizlerin gerçek ilişkileri yansıtabilmesi için ancak veri setlerinin aynı düzeyde durağan olmaları gerekmektedir (Gujarati ve Porter, 2009: 726):

$$
\Delta \mathrm{Y}_{t}=a_{0+} a_{1} t+\delta \mathrm{Y}_{t-1}+\sum_{i=1}^{N} \Psi \Delta Y_{t-1}+\varepsilon_{t}
$$

Yukarıda gösterilmekte olan denklemde $\Delta$ birinci farkını, $\mathrm{t}$ bir zaman trendini, $\varepsilon_{\mathrm{t}}$ hata terimini, $\mathrm{Y}_{\mathrm{t}}$ kullanılan serileri ve $\mathrm{N}$ ise hata terimleri arasındaki ardışık bağımlılığı gidermek için Akaike Bilgi Kriteri (AIC) tarafindan 
belirlenen bağımlı değişkenin gecikme sayısını ifade etmektedir. Bu şekildeki birim kök testleri, ADF testleri olarak belirtilmektedir. Serilerin durağan olması, alternatif hipotezi, serilerin durağan olmaması ise boş hipotezi ifade etmektedir.

Çalışmamızın son adımında, dış borç stoku ile iktisadi büyüme arasındaki nedensellik ilişkisi Granger Nedensellik testi ile araştırılmıştır. Nedensellik kavramı, değişkenler arasındaki ilişkinin yönünün (neden-sonuç ilişkisinin) istatistiksel olarak tespit edilebilmesi amacıyla Granger (1969) tarafından geliştirilmiştir. Bu bağlamda kurulan denklem aşağıdaki gibidir (Gujarati, 2006: 620):

$$
X_{t}=\sum_{i=1}^{n}\left(\begin{array}{l}
n \\
k
\end{array}\right) \mathrm{a}_{i} Y_{t-i}+\sum_{j=1}^{n} B_{j} X_{t-j}+u_{1 t}
$$

Regresyon analizlerinde değişkenlerin bağımlı veya bağımsız olmaları hususunda bir ön kabul durumu söz konusu olmakla birlikte değişkenler arasındaki bağımlılık ilişkisi araştırılmaktadır. Ancak nedensellik analizleri bir ön kabulden yola çıkmak yerine değişkenler arasındaki ilişkinin yönünü analiz etmeye dayanmaktadır. Bu noktada da nedensellik ilişkisinin iktisat teorisi tarafindan da doğrulanması beklenmektedir (Tarı, 2008: 418).

\section{Analiz ve ampirik bulgular}

Çalışmada kullanılan değişkenlerin bütünleşik yapıları, ADF testiyle araştırılarak eş-bütünleşme analizi için gerekli koşul sağlanmaya çalışılmıştır (Peker, 2008: 38). Bu hususta ADF testi sonuçları Tablo 2.'te gösterilmiştir.

Tablo 2. ADF birim kök testi sonuçları

\begin{tabular}{|l|l|c|c|c|}
\hline \multirow{2}{*}{ Değişkenler } & \multicolumn{1}{|c|}{ ADF test istatistiği } & \multicolumn{3}{|c|}{ Kritik değerler } \\
\cline { 3 - 5 } & & $\% 1$ & $\% 5$ & $\% 10$ \\
\hline$L T N$ & $-1.429909[11](0.5627)$ & -3.530030 & -2.904848 & -2.589907 \\
\hline$\Delta L T N$ & $-3.274[11](0.0003)$ & -4.530030 & -2.904848 & -2.589907 \\
\hline$L E X$ & $-2.526117[11](0.1137)$ & -3.525618 & -2.902953 & -2.588902 \\
\hline$\Delta L E X$ & $-5.641985[11](0.0000)$ & -3.525618 & -2.902953 & -2.588902 \\
\hline
\end{tabular}

Not: $\Delta$ sembolü değişkenlerin birinci farkını göstermektedir. Köşeli parantez Schwartz Kriterine göre belirlenmiş gecikme uzunluğu, normal parantez içinde ise olasılık değerleri yer almaktadır.

Elde edilen bulgularda, seriler düzey değerde birim kök içermekte, bir diğer ifadeyle durağan gözükmemektedir. Bu nedenle serileri durağan hale getirebilmek için birinci farkları alınmış ve serilerin birinci farklarının alınması sonrasında durağan hale geldiği gözlemlenmiştir. Bu bağlamda değişkenlere eş-bütünleşme testinden önce durağanlık testi yapılarak birim kök testi tekrar ele alınarak kurulduğunda hipotezler şu şekilde oluşmaktadir;

$H_{0}$ : Birim kök mevcuttur, seri durağan değildir.

$H_{1}$ : Birim kök yoktur, seri durağandır.

Değişkenlerin düzey seviyelerinde birim kök var olduğu ancak birinci farkları alındığında ise birim kökün ortadan kalktığından dolayı, $\mathrm{H}_{0}$ hipotezi reddedilerek, $\mathrm{H}_{1}$ hipotezi kabul edilmekte ve dolayısıyla analiz sürdürülebilmektedir. Durağanlık şartı sağlanan analizde, Johansen Eşbütünleşme yöntemi için ilk olarak uygun gecikme uzunlu VAR modeli ile test edilmiştir. Bu bağlamda uygun gecikme uzunluğu Tablo 3.'te gösterilmektedir.

Tablo 3. Uygun gecikme uzunluğu

\begin{tabular}{|c|c|c|c|c|c|c|}
\hline Lag & LogL & LR & FPE & AIC & SC & HQ \\
\hline 0 & 63.16957 & NA & 0.000477 & -1.973212 & -1.904595 & -1.946271 \\
1 & 70.33925 & 13.64552 & 0.000430 & -2.075460 & -1.869608 & -1.994637 \\
2 & 87.27136 & 31.13322 & 0.000284 & -2.492624 & -2.149538 & -2.357920 \\
3 & 103.7067 & $29.15946^{*}$ & $0.000190^{*}$ & $-2.893764^{*}$ & $-2.413443^{*}$ & $-2.705178^{*}$ \\
4 & 107.1302 & 5.853070 & 0.000194 & -2.875167 & -2.257612 & -2.632699 \\
5 & 107.7833 & 1.074450 & 0.000217 & -2.767203 & -2.012413 & -2.470853 \\
6 & 108.5784 & 1.256845 & 0.000242 & -2.663820 & -1.771796 & -2.313589 \\
7 & 11.5779 & 4.547529 & 0.000252 & -2.631544 & -1.602285 & -2.227431 \\
8 & 112.2888 & 1.031969 & 0.000282 & -2.525444 & -1.358951 & -2.067450 \\
9 & 113.3350 & 1.451266 & 0.000314 & -2.430162 & -1.126435 & -1.918286 \\
10 & 116.0627 & 3.607559 & 0.000332 & -2.389119 & -0.948157 & -1.823361 \\
\hline
\end{tabular}


Yukarıda gösterilen VAR modelinin doğrulama testlerinin hesaplanan sonuçlarına karşlık gelen gecikme uzunluğu; Final Prediction Error (FPE), Hannan Quinn Information Criteria (HQ), Akaike Information Criteria (AIC) ve Schwartz Information Criterion (SC) için üç olarak gerçekleşmiştir. Ancak üçüncü gecikme uzunluğunda model doğrulama testleri anlamlı sonuçlar vermediğinden, sekizinci gecikme uzunluğunda test edilerek analiz sürdürülmüştür.

Analizde uygun gecikme uzunluğunun belirlenmesi sonrasındaki aşama seriler arasında eş-bütünleşme yani, uzun dönemli bir ilişki olup olmadığını belirlemektir. Bu amaçla eş-bütünleşme analizinde uygun model seçimi yapılmalıdır. Burada değişkenler arasında uzun dönemli ilişsinin olup olmadığını test etmek için iz (trace) ve en büyük özdeğer (max eigen value) istatistikleri kullanılmıştır. Yapılan analiz ile elde edilen sonuçlar Tablo 4.'te gösterilmektedir.

Tablo 4. Johansen Eşbütünleşme analizi sonuçları

\begin{tabular}{|l|c|c|c|c|}
\hline $\begin{array}{c}\text { Eşbütünleşme } \\
\text { sayıs1 }\end{array}$ & Eigenvalue & $\begin{array}{c}\text { Trace istatistiği / } \\
\text { Max Eigen istatistiğ }\end{array}$ & \%5 Kritik değer & Olasılık değeri \\
\hline \multicolumn{5}{|c|}{ Trace istatistiği } \\
\hline Yok* & 0,275645 & 30,44344 & 25,87211 & 0,0126 \\
\hline En Çok 1 & 0,142047 & 9,805156 & 25,87211 & 0,1363 \\
\hline \multicolumn{5}{|c|}{ Max-Eigen istatistiği } \\
\hline Yok* & 0,275645 & 20,638229 & 19,38704 & 0,0328 \\
\hline En Çok 1 & 0,142047 & 9,805156 & 12,51798 & 0,1363 \\
\hline
\end{tabular}

Tablo 4.'teki sonuçlara göre turizm gelirleri ile dış borçlar arasında bir tane eş-bütünleşik vektör bulunmaktadır. Burada hem İz istatistiği hem de Max Özdeğer istatistiği sonuçlarına göre, turizm gelirleri ile dış borçlanmalar uzun dönemde birlikte hareket etmektedirler. Sonuçta, $\mathrm{H}_{0}$ yokluk hipotezi reddedilir. Ek olarak serilerin birinci farklarının doğrusal bileşimleri durağandır. Analizde hem İz İstatistiği hem de Max Özdeğer istatistiği için Model 4 (sabit terimli trendli) kullanılmışıır

Değişkenler arasında uzun dönemli ilişkinin olması halinde nedensellik ilişkisi hata düzeltme modeli (ECM) ile yapılmaktadır. Hata düzeltme parametresi, model dinamiğini dengede tutmaya yararken aynı zamanda değişkenleri uzun dönem denge değerine doğru yakınlaşmaya da zorlar. Hata düzeltme parametresindeki katsayıların istatistiksel bakımdan anlamlı çıkması, sapmanın varlığını gösterir ve katsayının büyüklüğü ise uzun dönem denge değerine doğru yakınlaşma hızının göstergesi şeklindedir (Çakın, 2019: 64). Tablo 5.'te hata düzeltme modelinin sonuçları yer almakta ve akabinde gerekli açıklamalar ifade edilmektedir.

Tablo 5. Hata düzeltme modeli

\begin{tabular}{|c|c|c|}
\hline Cointegrating Eq: & CointEq1 & \\
\hline DLEX(-1) & 1.000000 & \\
\hline \multirow[t]{3}{*}{ DLTN(-1) } & 0.262981 & \\
\hline & $(0.11854)$ & \\
\hline & [2.21849] & \\
\hline \multirow[t]{3}{*}{ @TREND(03Q1) } & 0.000815 & \\
\hline & $(0.00020)$ & \\
\hline & [ 4.07355] & \\
\hline $\mathrm{C}$ & -0.051805 & \\
\hline Error Correction: & D(DLEX) & $\mathrm{D}(\mathrm{DLTN})$ \\
\hline \multirow[t]{3}{*}{ CointEq1 } & -1.098477 & -3.720576 \\
\hline & $(0.30003)$ & $(5.29178)$ \\
\hline & {$[-3.66121]$} & {$[-0.70309]$} \\
\hline
\end{tabular}

Modelde, aralarında uzun dönemli eş-bütünleşik bulunan serilerde meydana gelecek herhangi bir sapmanın zamanla giderilip giderilmeyeceği konusu ele alınmıştır. Tutarlı bir modelde hata düzeltme katsayısının negatif ve istatiksel olarak anlamlı olması gerekmektedir. Aksi durumda kurulan model anlamsız olmaktadır. Tablo 5.'te elde edilen sonuçlarda test istatistiği (-3.66) ve hata düzeltme katsayısı negatif (-1.098) olarak gerçekleştiği görülmektedir. Burada test istatistiğinin mutlak değerinin 2.5' üzerinde olması, modelin \%1 anlamlı olduğunu göstermektedir. Aynı zamanda hata düzeltme katsayısının negatif olması ise yine modelin anlamlı olduğunu ve uzun dönem dengesinde sapmalar meydana geldiği zaman kısa dönemde dengesizliğin düzeltilebileceği şeklinde ifade edilmektedir. Yalnız, bir değişkende bile bu katsayının negatif olması bu modelin anlamlı ve çalışır durumda olduğunu 
göstermektedir. Uzun dönem ilişki içerisinde bulunan ve eşbütünleşik olan turizm gelirleri ve dış borç serileri Tablo 5.'ten elde edilen bulgulara göre normalize edilerek eşbütünleşik bir denklem kurulabilir. Bu denklem aşağıdaki gibidir:

$$
\Delta L E X=-0.262 \Delta L T N
$$

Yukarıda ifade edilen (6) no'lu denkleme göre, uzun dönemde turizm gelirlerinde meydana gelen \%1'lik artış, dış borçlarda $\% 0.262$ oranında bir azalmaya neden olmaktadır. Elde edilen bu sonuç, kurulan model çerçevesinde anlamlı ve tutarlıdır. Hata düzeltme modelinden (ECM) sonra değişkenler arasında otokorelasyon sorunun olup olmadığına bakılıp, otokorelasyon bulunmaması durumunda, seriler arasındaki nedensellik ilişkisine hata düzeltme modeli üzerinden Granger Nedensellik analizine bakılacaktır. Bu bağlamda modele ilişkin otokorelasyon testi sonuçları Tablo 6.'da gösterilmektedir.

Tablo 6. Otokorelasyon testi sonuçları

\begin{tabular}{|c|c|c|}
\hline Gecikme uzunluğu & LM-istatistiği & Olasilık değeri \\
\hline 1 & 1.989654 & 0.7377 \\
2 & 1.965258 & 0.7421 \\
3 & 4.049398 & 0.3994 \\
4 & 2.556377 & 0.6346 \\
5 & 1.499858 & 0.8267 \\
6 & 1.500627 & 0.8265 \\
7 & 4.555237 & 0.3360 \\
8 & 9.024000 & 0.0605 \\
9 & 5.601479 & 0.2310 \\
10 & 1.236271 & 0.8721 \\
\hline
\end{tabular}

Johansen Eşbütünleşme analizi öncesinde tahmin edilen en uygun gecikme uzunluğu sekiz olarak ele alınmış ve bu bağlamda Tablo 6.'da yer alan sekizinci gecikme uzunluğunda olasıllk değerinin 0.06 olduğu ve dolasıyla $\% 1$ ve $\% 5$ kritik değerden büyük olduğu için kurulan modelde otokorelasyon sorununun olmadığı ve dolayısıyla modelin anlamlı ve tutarlı olduğu görülmektedir.

Tablo 7. Granger Nedensellik testi sonuçları

\begin{tabular}{|c|c|c|c|}
\hline Bağımlı değişken: Dış borçlar & \\
\hline Dışlanan & Ki -kare & df & Olasılık \\
Turizm Gelirleri & 17.35558 & 8 & 0.0266 \\
Hepsi & 17.35558 & 8 & 0.0266 \\
Bağımlı Değişken: Dış Borçlar & & & \\
Dış Borçlar & 4.034400 & 8 & 0.8540 \\
Hepsi & 4.034400 & 8 & 0.8540 \\
\hline
\end{tabular}

Granger nedensellik testi, bu çalışmada, turizm gelirleri ile dış borçlar arasındaki ilişkiyi test etmek için 2003Q1'den 2021Q1 yılına kadar olan veriler ile donatılmıştır. Tabloda da görüldüğü üzere, turizm gelirlerinden dış borçlara doğru tek yönlü bir nedensellik olduğu tespit edilmiştir. Elde edilen bu tek yönlü nedensellik testi sonucunda modelin genelinin anlamlı olduğu görülmüştür. Dolayısıyla ele alınan dönem içerisinde uzun dönem ilişki içerisinde yer alan bu iki değişken arasında tek yönlü bir nedensellik ilişkinin mevcut olduğu ve modelin bu suretle anlamlı olduğu ortaya koyulmaktadır.

\section{Sonuç ve değerlendirme}

Ülke ekonomileri açısından döviz cinsinden elde edilecek olan kaynaklar oldukça önemlidir. Çünkü bu kaynaklar; ülkeler için uluslararası bir ödeme gücü yaratmakta, yeni yatırımlara olanak tanımakta, dış ticaretin büyümesini sağlamaktadır. Bu gibi faktörler, kümülatif olarak ülkelerin iktisadi gelişimini desteklemektedir. Bu bağlamda turizm gelirleri ve dış borçlanmalar, ülke ekonomilerine sağladığı döviz cinsinden fon kaynağı sebebiyle oldukça önemli iki değişken olarak karşımıza çıkar. Turizm gelirleri ve dış borçlanmalar, döviz cinsinden olan kazanımları ile benzerlik gösterirken, yine kayıpları açısından da benzerlik arz etmektedirler. Öyle ki ülkeler daha fazla turizm geliri elde edebilmek için yatırımlara ve akabinde daha fazla fon gereksinimine ihtiyaç duymaktadır. Bu ihtiyacın karşılanması için ülkeler dış kaynaklara başvurabilir ve bu dış kaynaklar ile turizm yatırımları gerçekleştirilebilir. Ancak başvurulan dış borçlar için tediye süresince bir döviz ihtiyacı doğmaktadır. Böylece elde 
edilmesi beklenen turizm gelirleri ile başvurulan dış kaynakların tediyesi gerçekleştirilebilir. Dolayısıyla turizm gelirlerinin, dış borçlanmaların tediyesi sürecinde ülke ekonomileri için ayrıca bir ödeme gücü de sağladığı açıktır.

$\mathrm{Bu}$ araştırma, daha önce yapılan araştırmalardan farklı olarak, turizm gelirleri ve dış borçlar arasındaki ilişkiyi spesifik olarak ele almakta ve bu bağlamda literatüre yeni bir bakış açısı sunmaktadır. Türkiye ekonomisi için 2003Q1 ve 2021Q1 yılları arasında çeyreklik veriler ile Johansen-Juselius Eşbütünleşme ve Granger Nedensellik yöntemiyle gerçekleştirilen analizde ilk olarak serilere standart birim kök testi uygulanmış ve seriler durağan hale getirilmiştir. Akabinde uygun gecikme uzunluğu sekiz olarak tespit edilmiş ve Eşbütünleşme analizine geçilmiştir. Eşbütünleşme analizi sonucunda turizm gelirleri ile dış borçlar arasında bir tane eşbütünleşik vektör bulunmuş ve bu iki değişkenin uzun dönemde birlikte hareket ettiği tespit edilmiştir. Eşbütünleşme analizi sırasında ortaya çıkan veri kaybının yol açtığı sıkıntıları ortadan kaldırmak ve değiş̧kenler arasındaki ilişkinin yönü hakkında bilgi sahibi olabilmek için serilere hata düzeltme modeli uygulanmış ve uygulanan bu hata düzeltme modeli sonuçlarında uzun dönemde turizm gelirlerinde meydana gelen $\% 11^{\prime}$ lik artışın dış borçlanmalarda $\% 0.262$ oranında bir azalmaya sebep olduğu görülmüş̧ür.

Elde edilen sonuçların doğrulanması sonrasında uygulanan Granger Nedensellik testi sonuçlarında, 2003Q1 ve 2021Q1 arasında Türkiye ekonomisinde turizm gelirlerinden dış borçlanmalara doğru tek yönlü bir nedensellik olduğu tespit edilmiş ve analizin anlamlı ve tutarlı olduğu görülmüştür.

Türkiye ekonomisi için yapılan bu araştırmaya göre, ele alınan yıllarda elde edilen turizm gelirleri dış borçlanmanın azalmasını sağlamaktadır. Ortaya çıkan bu sonuç, ele alınan yıllarda uygulanan ekonomi politikaları ile de ilişkilidir. Türkiye'nin 2003 yılı sonrasında hızla artan dış borçlanmaları ve turizm gelirleri arasındaki ilişkinin, aslen turizmin bir ödeme gücü yaratarak dış borçlanmaların tediyesinin sağlanmasına veyahut dış borç kaynağına daha az başvurulmasına vesile olmaktadır. Dolayısıyla turizm gelirlerinin Türkiye ekonomisi için önemi oldukça geniş bir yelpazede hissedilmektedir. Bu hususta politika yapıcıları tarafından turizm gelirlerinin arttırılması için gerekli politikaların uygulanması ve ele alınması oldukça elzemdir. Ayrıca Türkiye'de, başvurulan dış kaynakların verimli alanlarda yani turizm sektörü gibi döviz girdisi sağlayabilen yatırımlarda kullanımı oldukça önemlidir. Diğer bir ifadeyle Türkiye ekonomisinde alınan dış borçlar, tediye süreçleri de hesaplara katılarak, verimli ve etkin alanlarda kullanılmalıdır. Burada, dış kaynaklara başvurmadan önce gerek politika yapıcıları gerekse özel sektör yöneticileri tarafınca iyi bir strateji belirlenmeli ve gerekli maliyet - gelir hesaplamaları yapılarak ona göre hareket edilmelidir. Bu perspektif çerçevesinde turizm gelirleri ve dış borçlanmalar arasındaki ilişki önemli bir konu niteliğine sahip olabilir.

\section{Yazarların katkı oranı beyanı}

Yazarlar makalenin veri toplama, veri analizi, raporlaştırma ve diğer aşamalarından eşit düzeyde sorumlu olduğunu beyan ederler.

\section{Çıkar çatışmast}

Bu çalışmada yazarlar tarafindan herhangi bir çıkar çatışması belirtilmemiştir.

\section{Etik kurul onayt}

Bu çalışma ekonomi alanında olup, 2003Q1 ve 2021Q1 dönemi arasında çeyreklik veriler kullanılmıştır. İnsan üzerine veri, toplama, analizi ya da sonuçları ile ilgili olmadığı için Etik Kurul Onayı gerekmemektedir. Tüm sorumluluk yazara aittir.

\section{Kaynakça}

Ceylan, R. ve Başer, S. (2014). Türkiye'de Petrol Tüketimi ile Reel GSYİH Arasındaki Uzun Dönem İlişkinin Johansen EşBütünleşme Yöntemi ile Analiz Edilmesi. Business and Economics Research Journal, 5(2), 47-60

Cho, V. (2003). A Comparison of Three Different Approaches to Tourist Arrival Forecasting. Tourism Management, 24 (3), 323-330.

Çakın M. (2019). Kripto Paralar; Bitcoin, Döviz Kurları ve Alternatif Kripto Paralar Arasındaki İlişkinin İncelenmesi. Yüksek Lisans Tezi, Dokuz Eylül Üniversitesi, Sosyal Bilimler Enstitüsü, İzmir.

Demir, E. (2018). Dış Borçların Enflasyon Üzerine Etkisi: Türkiye Örneği (1990-2017). Yüksek Lisans Tezi, Adnan Menderes Universitesi Sosyal Bilimler Enstitüsü, Aydın.

Demir, E., ve Bahar, O. (2021). Turizm gelirlerinin ekonomik büyüme üzerine etkisi: Türkiye üzerine ampirik analiz. International Journal of Social Sciences and Education Research, 7 (2), 162-172. 
Gökoval1, U. ve Bahar, O. (2006). Contribution of Tourism to Economic Growth in Mediterrranean Countries: A Panel Data Approach, Anatolia An International Journal of Tourism And Hospitality Research, 17 (2), 155-168

Gujarati, D. N. (2006). Temel Ekonometri (Dördüncü Baskı) (Çeviren: Ümit Şenesen ve Gülay Günlük Şenesen). İstanbul: Literatür Yayıncilık

Gujarati, D. ve Porter, C., D. (2009). Basic Econometris (Beşinci Baskı). Boston: Mc Grawhill

Jayawardena, C. and Ramajeesingh, D. (2003). Performance a Tourism Analysis: A Carinneam Perspective. International Journal of Contemporary Hospitality Management, 15 (3), 165-183.

Karluk, R. (2007). Türkiye Ekonomisi (onbirinci Baskı). İstanbul: BETA Yayınları

Pearce, D. W. (1991). Tourist Development. New York: Longman

Peker, O. (2008). Reel Döviz Kurunun Ticaret Dengesi Üzerindeki Etkileri: Türkiye Örneği. İktisadi ve İdari Bilimler Dergisi, 22(2), 33-43.

Seyidoğlu, H. (2003). Uluslararası İktisat, Teori, Politika ve Uygulama (onbeşinci Baskl). İstanbul: Güzem Can Yayınları.

Sharpley, R. (2006). Travel and Tourism. California: SAGE Publications Ltd

Tarı, R. (2008). Ekonometri (Beşinci baskı). İstanbul: Avcı Ofset Yayınları.

Tuna, H. (2019). Dış Borçlanma ve Ekonomik Büyüme İlişkisi: Türkiye Üzerine Ampirik Bir Uygulama (1980-2017), (Yüksek Lisans Tezi). Karamanoğlu Mehmet Bey Üniversitesi Sosyal Bilimler Enstitüsü, Karaman.

Türk, İ. (2003). Maliye Politikası Amaçlar, Araçlar ve Çağdaş Bütçe Teorileri. Ankara: Turhan Kitabevi Yayınları

Yavuz, N. Ç. (2006). Türkiye'de Turizm Gelirlerinin Ekonomik Büyümeye Etkisinin Testi: Yapısal Kırılma ve Nedensellik Analizi. Doğuş Üniversitesi Dergisi, 7 (2), 162-171

Yılmaz, B. E. (2010). Devlet Borçları. İstanbul: İstanbul Üniversitesi Açık ve Uzaktan Eğitim Fakültesi Yayınları. 


\section{Extended Abstract}

The resources to be obtained in foreign currency are very important for the economies of the countries. Because these resources; It creates an international solvency for countries, enables new investments, and ensures the growth of foreign trade. Such factors cumulatively support the economic development of countries. In this context, tourism revenues and foreign borrowings appear as two very important variables due to the foreign currency funds they provide to the national economies.

Within the framework of the Keynesian policies followed by the world economies after the Second World War, the economies constantly resorted to external resources in order to meet the need for funds to ensure economic development. In addition to these external borrowings, which are applied to fill the foreign currency fund deficit, tourism revenues have become a very important foreign currency source in the periodic perspective. Because, within the global transformations experienced, tourism has become very popular with the effect of technology and welfare, has gained diversity in many aspects and has become an important sector in meeting the foreign currency fund deficit that the country's economies need. So much so that within the scope of these economic and social developments, according to the World Tourism Organization (WTO), which is within the body of the United Nations (UN), tourism has been described as the largest and most comprehensive area of economic activity in the world. Thus, in addition to foreign borrowings, tourism has become an important resource in the economic development of countries with the foreign exchange revenues obtained, and countries have made large investments in order to get a larger share from this resource. Therefore, tourism has attracted great interest in both developed and developing countries due to its gains. This interest in the tourism sector has come to the fore especially in the economies of countries where the amount of foreign debt is high and there is a deficit of funds in foreign currency.

Foreign borrowing is an economy item that mostly developing countries apply, but it is also an important source of funding for developed countries. When the development processes of developed countries are examined, it is seen that these countries have resorted to external debt in order to eliminate the necessary funds. Countries such as England, Sweden, the United States of America (USA), and Japan, which are among the developed countries, are examples of this parable. External borrowing both eliminates the inadequacy of domestic savings and provides the ability to pay in foreign currency. While there is an increase in domestic resources when external borrowing is made, decreases may occur when it is repaid. For this reason, the necessity for economies applying to the foreign debt item to use their debt in productive areas is an important factor in terms of not experiencing difficulties in the economic dynamics during the repayment of external debt. In this regard, it is usual for the tourism sector to be seen as an efficient investment position within the framework of the foreign funds provided for the countries, since the tourism revenues obtained are in foreign currency like foreign borrowings.

The size of the investments made by the countries to increase their tourism revenues increases their expenditures in these countries and pushes them to seek new funds. It is normal that this fund need cannot be obtained from internal resources, leading countries to external resources. The supply of the costs created by this orientation can be expected from the tourism sector, which is originally invested. Thus, the larger the amount of funds invested in this context, the greater the expected income can be. In this regard, it is possible to say that the nature of tourism revenues and foreign borrowings for national economies are similar. In this similarity, the fact that these two variables are in foreign currency comes first.

There are various macroeconomic variables that provide foreign exchange inflows for the developing Turkish economy. However, among these, tourism revenues and external borrowing are among two very important variables. Because when it comes to the international tourism sector, Turkey's potential provides great advantages in order to obtain these incomes. In order to benefit from these advantages, Turkey made significant investments, especially after 1980, and tried to increase its share of international tourism revenues. However, in order to meet the need for funds for increasing investments in Turkey, foreign borrowing was applied and for this reason, it was seen that the increase in foreign borrowings increased rapidly after 1980.

The aim of the study is to reveal the relationship between tourism revenues and foreign borrowing for the Turkish economy. Unlike previous studies, this research specifically addresses the relationship between tourism revenues and external debt and offers a new perspective to the literature in this context. For the Turkish economy, in the analysis performed with the quarterly data between 2003Q1 and 2021Q1 with the Johansen-Juselius Cointegration and Granger Causality method, the standard unit root test was first applied to the series and the series became stationary. Then, the appropriate lag length was determined as eight and cointegration analysis was started. As a result of the cointegration analysis, a cointegrating vector was found between tourism revenues and external debt, and it was determined that these two variables act together in the long run. In order to eliminate the problems 
caused by the loss of data during the cointegration analysis and to have information about the direction of the relationship between the variables, the error correction model was applied to the series and as a result of this error correction model applied, the $1 \%$ increase in tourism revenues in the long term was $0.262 \%$ in external borrowing. was found to cause a decrease. In the results of the Granger Causality test applied after the validation of the results obtained, it was determined that there was a one-way causality from tourism revenues to foreign borrowing in the Turkish economy between 2003Q1 and 2021Q1 and the analysis was found to be significant and consistent.

According to this research conducted for the Turkish economy, tourism revenues obtained in the years discussed provide a reduction in foreign borrowing. This result is also related to the economic policies implemented in the years discussed. The relationship between Turkey's rapidly increasing external borrowings after 2003 and tourism revenues, in fact, creates a payment power of tourism, thus providing the payment of foreign borrowings or making less use of external debt resources. Therefore, the importance of tourism revenues for the Turkish economy is felt in a wide range. In this regard, it is essential for policy makers to implement and address the necessary policies to increase tourism revenues. In addition, in Turkey, the use of external resources in productive areas, such as the tourism sector, is very important in investments that can provide foreign currency inflows. In other words, foreign debts taken in the Turkish economy should be used in efficient and effective areas by taking into account the payment processes. Here, before applying to external resources, a good strategy should be determined by both policy makers and private sector managers and the necessary cost-revenue calculations should be made and acted upon. Within the framework of this perspective, the relationship between tourism revenues and external borrowing may be an important issue. 